\title{
ANALISA KESEKATAN SESAR DAN KOMPARTEMEN LAPISAN BERDASARKAN ANALISIS PETROFISIKA DAN ATTRIBUT SEISMIK PADA FORMASI TALANG AKAR, SUB CEKUNGAN JAMBI
}

\author{
Eko Wibowo \\ Prodi Teknik Teknik Geofisika, FTM, Universitas Pembangunan Nasional "Veteran" Yogyakarta \\ Coresponding author.email :wibowo.ekogeofisika69@yahoo.com
}

\begin{abstract}
Abstrak
Daerah penelitian terletak pada Sub Cekungan Jambi. Fokus utama dalam penelitian ini adalah melakukan pendekatan mengenai stuktur yang berkembang di daerah penelitian yang dapat bersifat sebagai tempat akumulasi atau jalur migrasi dengan menggunakan metode SGR (Shale Gauge Ratio), rekonstrusi tektonik berdasarkan data seismik diharapkan dapat menjawab kompartemenisasi lapisan reservoar pada Formasi Talang Akar dan migrasi fluida hidrokarbon pada reservoar.

Berdasarkan analisis terhadap sumur Alpha-1 dan Betha-1 terdapat lapisan prospek hidrokarbon yang merupakan lapisan Formasi Talang Akar. Pada Alpha-1 zona prospek berada pada kedalaman 1436,6 - 1456,6 m (TVDSS) diberi nama TAF 1 memiliki porositas efektif rata-rata 0,1281 ; saturasi air rata-rata 0,34 dengan nilai $R_{t}$ rata-rata $1794 \mathrm{ohm} \mathrm{m}$ dan $R_{w} 0,4 \mathrm{ohmm}$. Pada sumur Betha-1 zona prospek berada pada kedalaman $1448 \mathrm{~m}$ - 1456,5 m (TVDSS) dengan porositas efektif rata-rata pada zona ini 0,129 ; saturasi air rata-rata 0,586 dengan nilai $R_{t}$ rata-rata $32,2 \mathrm{ohm} \mathrm{m}$ dan nilai $\mathrm{Rw} 0,9 \mathrm{ohmm}$. Sifat kesekatan sesar pada sesar yang dianalisa adalah leak dengan ratio SGR $15 \%$, serta lapisan yang tersesarkan merupakan lapisan reservoar dari Formasi Talang Akar yang sama. Pergerakan fluida hidrokarbon (migrasi) terjadi secara intraformasi (terjadi pada formasi yang sama).
\end{abstract}

Kata kunci: Shale Gauge Ratio, Seismik Attribut, Porositas, Saturasi

\begin{abstract}
The research area is located in the Jambi Sub-Basin. The focus of this study was the structure in this sub basin, fault which can be a trap or migration route, which can defined using SGR (Shale Gauge Ratio) method. This study also resulted in reconstruction of the tectonics history to know the compartements between reservoir (Talang Akar Formation) and to know the migration of hydrocarbon.

Based on the analysis of the well Alpha-1 and Betha-1, there is a layer of hydrocarbon prospects in Talang Akar Formation. At ALPHA 1, prospect zone at depth of 1436.6 to $1456.6 \mathrm{~m}$ (TVDSS) named TAF 1 has an average effective porosity 0.1281 , the average water saturation of 0.34 with an average permeability in this zone is $20, R_{t} 62 \mathrm{mD}$ with an average value of $1794 \mathrm{ohm} \mathrm{ohm} m$ and $R_{w} 0.4 \mathrm{~m}$. The Betha- 1 wells prospects zone at depth of $1448 \mathrm{~m}-1456,5 \mathrm{~m}$ (TVDSS) with an average effective porosity in this zone is 0,129 average water saturation of 0,586, permeability 19,6 mD with an average value of $R_{t} 32,2$ $\mathrm{ohm} \mathrm{m}$ and $\mathrm{Rw}$ value of $0,9 \mathrm{ohm} \mathrm{m}$. The conclusion of fault seal in analysis that separated two layers is leaking with SGR ratio of $15 \%$, as well as layers that faulted the reservoir layer of the same Talang Akar Formation. The movements of hydrocarbon as intraformation (in one formation migration).
\end{abstract}

Key words: Shale Gauge Ratio, SeismicAttribute, Porosity, Saturation

\section{Pendahuluan}

Permasalahan muncul ketika penggunaan sumber daya mineral dan bahan bakar fosil tidak dengan bijaksana digunakan, penggunaan secara berlebihan dan terus menerus tanpa melakukan eksplorasi baru. Permasalahan ini sering kali terjadi pada ketersediaan bahan bakar fosil (minyak dan gas bumi) padahal Indonesia merupakan negara yang memiliki sumberdaya minyak dan gas bumi dalam jumlah yang melimpah. Diperkirakan cadangan minyak dan gas bumi di Indonesia sebesar 87,22 miliar barrel dan 594,43 TSCF tersebar di Indonesia (ESDM, 2015).

Bahan bakar fosil yang telah dikenal dan banyak digunakan adalah batubara, minyak dan gas bumi. Pada kesempatan kali ini, penulis akan memfokuskan minyak dan gas bumi sebagai bahan kajian. Secara konsepsional, deposit minyak dan gas bumi akan dipengaruhi oleh beberapa faktor dikenal dalam konsep Petroleum System, antara lain adalah source rock, reservoir rock, seal rock, 
migration route dan trap. Salah satu cekungan penghasil hidrokarbon terbesar di Indonesia adalah Cekungan Sumatera Selatan. Cekungan Sumatera Selatan terdiri dari beberapa sub cekungan, yaitu Sub Cekungan Jambi, Sub Cekungan Palembang Utara, Sub Cekungan Palembang Tengah dan sub cekungan Palembang Selatan (Bishop, 2001). Penelitian dilakukan pada Sub Cekungan Jambi lapangan X. Kontrol struktur sangat berpengaruh pada pelamparan lapisan dari reservoar. Tinggi rendahnya pola basement juga merupakan sebagai akibat dari struktur yang terjadi pada daerah penelitian. Pola tinggian dan rendahan di basement mempengaruhi pola kemenerusan dari Formasi Talang Akar, hal lainnya yang menarik sebagai akibat adanya struktur adalah pola migrasi fluida hidrokarbon.

Migration route atau jalur migrasi dapat didefinisikan sebagai jalur yang dapat digunakan oleh fluida yang terkandung dalam batuan untuk bergerak, jalur migrasi ini tentu saja dapat berupa penjajaran lapisan yang memungkinkan bergeraknya fluida, atau melalui retakan (kekar) dan patahan (sesar) yang menghubungkan antara batuan berbeda yang memiliki sifat sebagai reservoir. Sedangkan, trap merupakan tempat terakumulasi fluida, akumulasi fluida dapat terjadi akibat adanya pensejajaran lapisan reservoir dan non reservoir, dapat pula terjadi akibat adanya variasi litologi pada lapisan yang sama (beda fasies) atau dapat pula akumulasi fluida diakibatkan hadirnya sesar atau patahan yang bersifat seal, sehingga fluida tidak dapat bergerak.

Berdasarkan penjelasan diatas bahwa keberadaan migration route dan trap menjadi faktor yang paling menentukkan terhadap jumlah minyak dan gas bumi yang dapat dimanfaatkan. Sehingga studi ini akan membahas kemungkinan sesar menjadi trap atau migration route. Analisa kesekatan sesar adalah langkah pertama yang dilakukan untuk mengetahui pola kompartemenisasi, hal ini dikarenakan untuk mengetahui sifat sesar. Sesar yang bersifat leak cenderung akan memberikan gambaran bahwa blok di hanging dan footwall memiliki komunikasi atau merupakan bagian sama yang berkompartmen. Sesar yang bersifat leak, cenderung memiliki vertical displacement yang kecil, sehingga kemungkinan bahwa reservoar berada dalam satu lapisan yang sama akan besar. Selanjutnya, dari properties petrofisika yang dianalisa, lapisan yang sama akan memiliki nilai properties batuan yang tidak jauh berbeda.

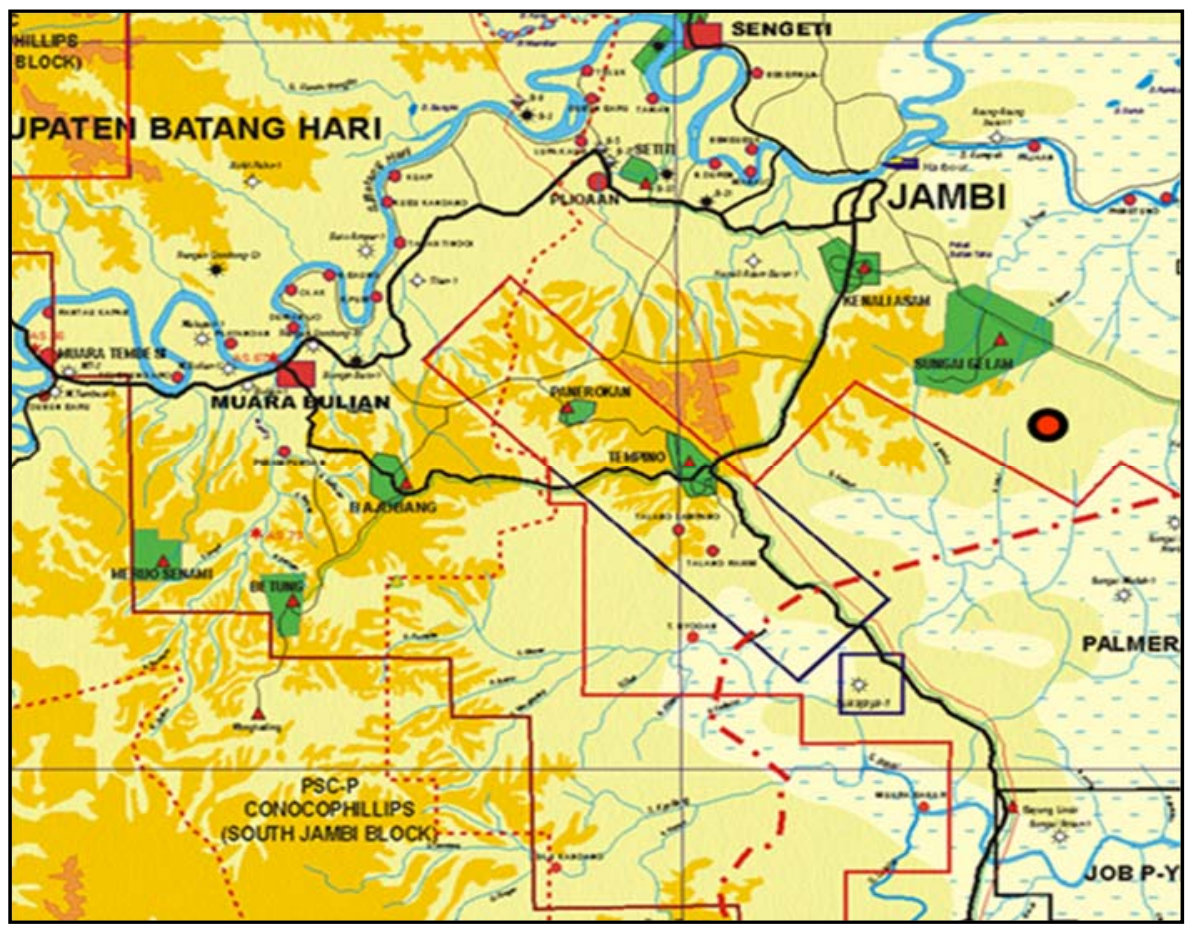

Gambar 1. Peta Lokasi Penelitian 


\section{Metodologi}

Analisis data dilakukan pada Lapangan " $X$ " yang terdapat di daerah Jambi dan berada pada struktur Bungin Batu - Rengan Condong kurang lebih $60 \mathrm{~km}$ di sebelah barat daya kota Jambi dan dapa dilihat pada Gambar 1. Daerah ini merupakan salah satu lapangan minyak dan gas bumi yang dikelola oleh Pertamina.

\subsection{Prosedur penelitian}

Adapun prosedur penelitian sebagaimana dapat dilihat pada diagram alir seperti dapat dilihat pada Gambar 2.
Data yang digunakan dalam penelitian ini terdiri dari data seismik, data well log, data checkshot dan data well report (Gambar 3). Data well report digunakan untuk mengkalibrasi formasi batuan kedalaman tertentu hasil intepretasi log.

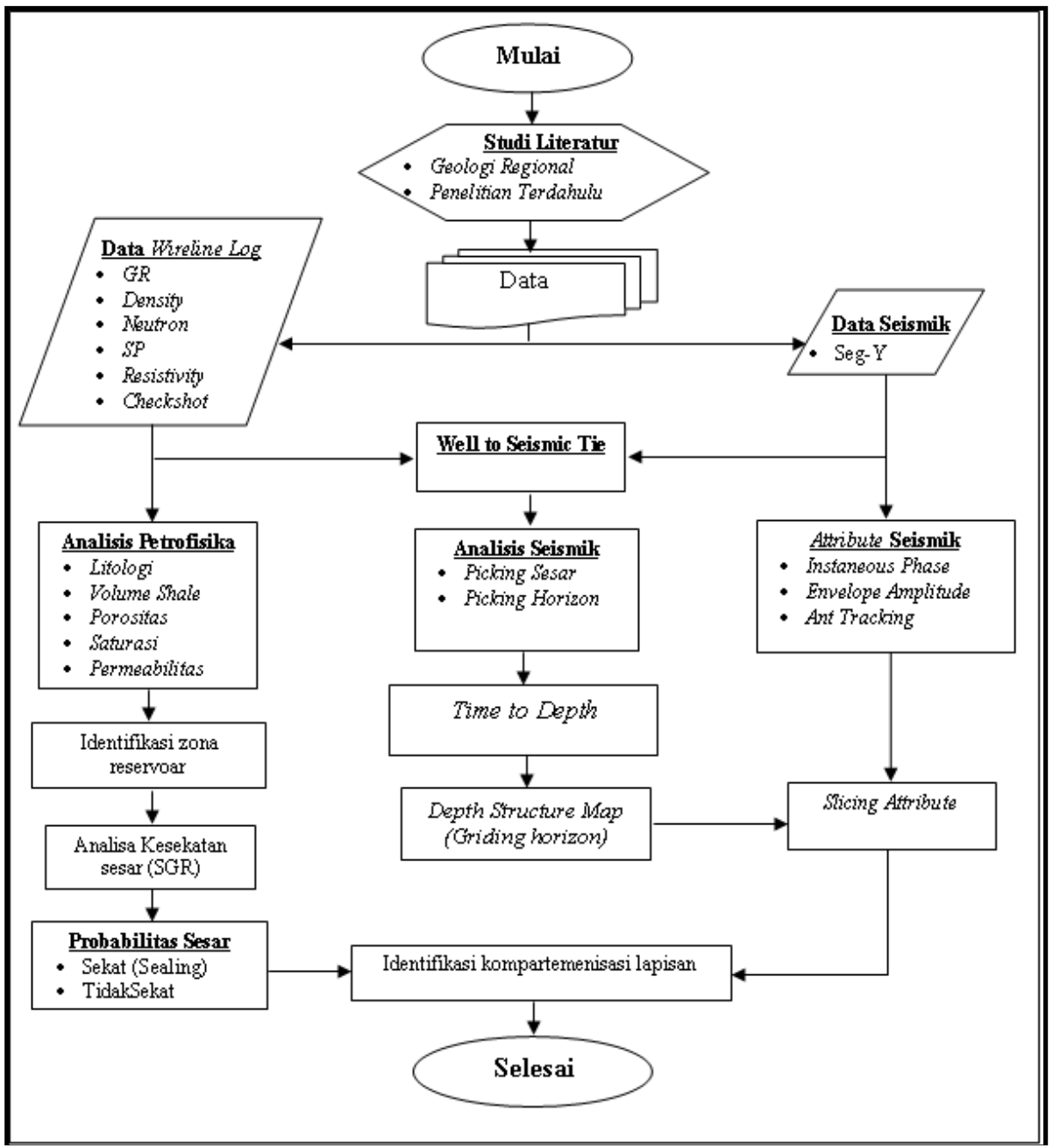

Gambar 2.Diagram alir penelitian 


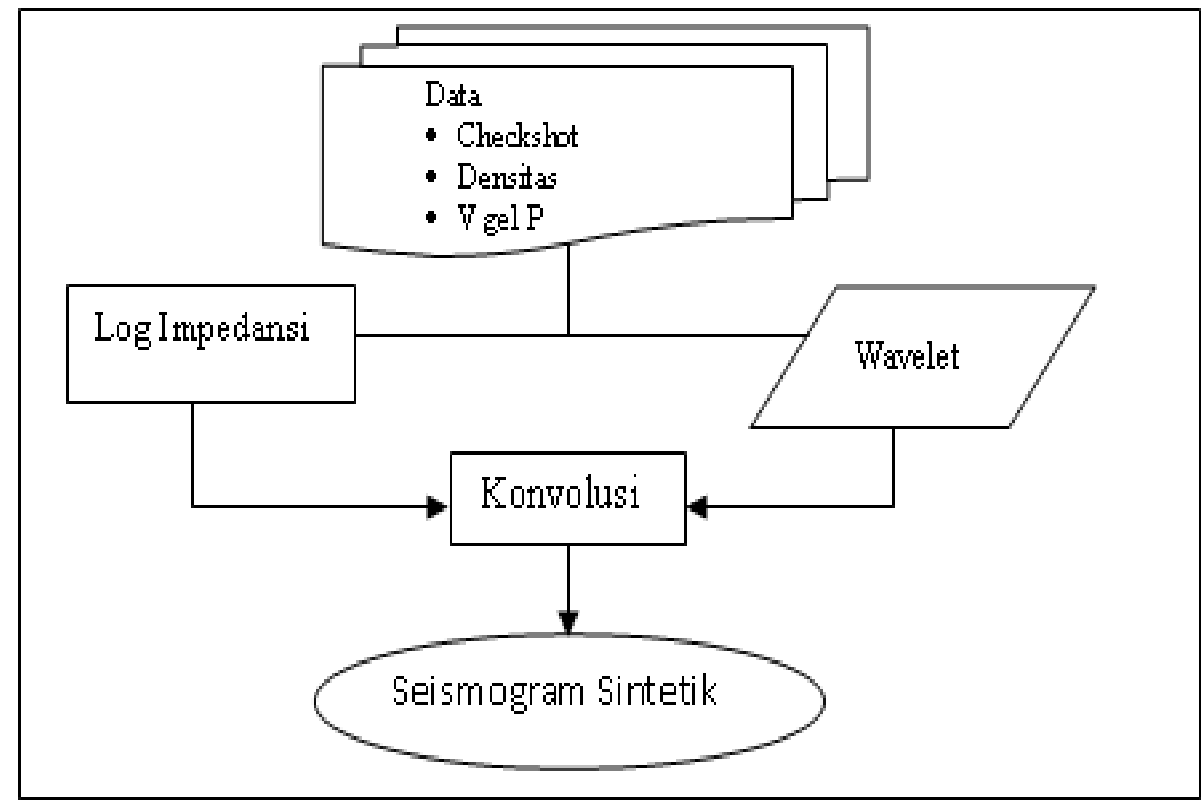

Gambar 3. Diagram alir pengolahan data

\subsection{Prosedur Well Seismic Tie}

Proses well seismic tie merupakan proses mengikat data sumur (zona prospek) dalam domain kedalaman dengan data seismik dalam domain waktu.

\section{Hasil dan Pembahasan}

\subsection{Identifikasi Reservoir}

Pengolahan data dibagi dalam dua tahap yaitu, penentuan zona prospek, kemudian dari beberapa zona prospek ini akan dianalisa lebih lanjut satu zona yang menarik dan memiliki kaitan dengan struktur. Pengolahan data dilakukan dengan menggunakan program GeoGraphix untuk melakukan analisa terhadap sumur daerah telitian dan Petrel digunakan untuk melakukan intepretasi berkaitan dengan pelamparan lapisan reservoir dan struktur yang berkembang di lapangan $\mathrm{X}$, time slicing dilakukan pada atribut seismik untuk membantu penentuan pola kompartemenisasi dengan menggunakan software Petrel. Untuk analisa pertama dilakukan terhadap data sumur, analisa terhadap data sumur ini dilakukan dalam beberapa jenis analisa, yaitu :

1. Analisis kualitatif. Analisis ini merupakan bagian dari analisis di dalam menentukan sifat petrofisika batuan reservoir. Analisis ini terdiri dari beberapa hal yaitu : identifikasi litologi dan keberadaan fluida. Analisis ini dilakukan dengan menggunakan data log mekanik sumur Alpha-1 dan Betha-1 yaitu log sinar gamma (GR), $\log$ resistivitas yaitu log MSFL dan $\log$ LLD, log porositas yaitu log densitas dan neutron.

2. Analisis kuantitatif. Analisis ini terdiri dari penentuan nilai kandungan serpih, porositas, permeabilitas serta kejenuhan air. Penentuan sifat-sifat petrofisika tersebut menggunakan persamaan Archie, persamaan Simandoux dan persamaan Indonesia.

3. Penentuan zona prospek hidrokarbon. Setelah dilakukan analisis kualitatif dan kuantitatif maka dapat ditentukan zona prospek hidrokarbon yang paling baik. 
Jurnal OFSHORE, Volume 1 No. 2 Desember 2017 : 10 - 21 ; e -ISSN : 2549-8681

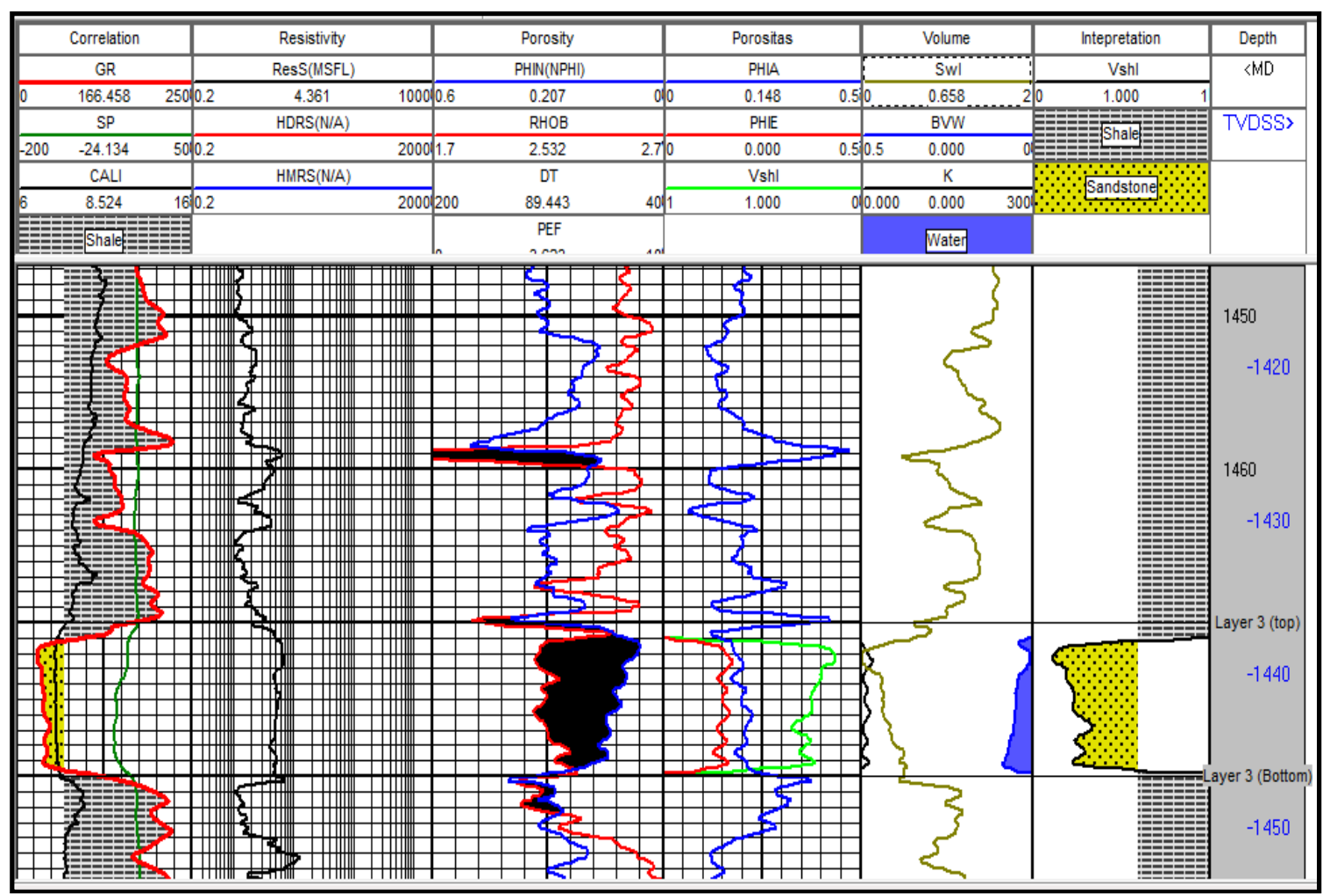

Gambar 4. Karakter log daerah telitian (Alpha-1) zona 1 (TAF 1)

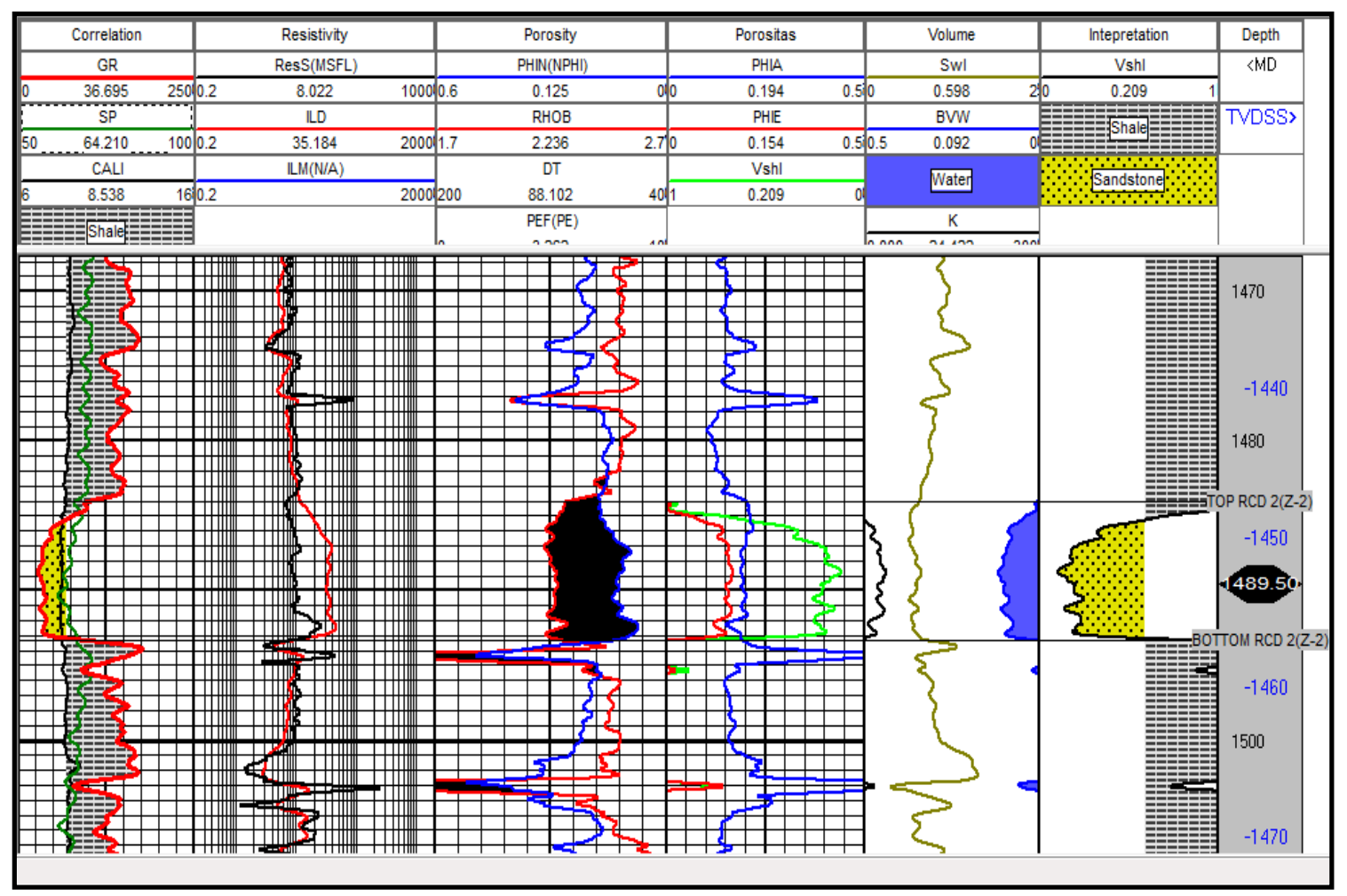

Gambar 5. Karakter log daerah telitian (Betha-1) zona 1 (TAF 1) 


\section{ANALISA KESEKATAN SESAR DAN KOMPARTEMEN LAPISAN BERDASARKAN ANALISIS PETROFISIKA DAN ATTRIBUT SEISMIK PADA FORMASI TALANG AKAR, SUB CEKUNGAN JAMBI}

Pada sumur Alpha-1 dengan karakter log yang ditunjukkan pada Gambar 4, zona prospek berada pada kedalaman 1436,6 - 1456,6 m (TVDSS) diberi nama TAF 1 memiliki porositas efektif rata-rata 0,1281 , saturasi air rata-rata 0,34 dengan permeabilitas rata-rata pada zona ini adalah 20,62 mD dengan nilai Rt rata-rata 1794 ohm m dan Rw 0,4 ohm m. Pada sumur Betha-1 dengan karakter defleksi log yang ditunjukkan pada Gambar 5, zona prospek berada pada kedalaman $1448 \mathrm{~m}$ - 1456,5 m (TVDSS) diberi nama TAF 1 dengan porositas efektif rata-rata pada zona ini 0,129 saturasi air rata-rata 0,586 , permeabilitas $19,6 \mathrm{mD}$ dengan nilai Rt rata-rata $32.2 \mathrm{ohm} m$ dan nilai $\mathrm{Rw} 0,9 \mathrm{ohm} \mathrm{m}$.

\subsection{Korelasi Sumur Alpha-1 dan Betha-1}

Korelasi antara sumur Alpha-1 dan Betha-1 dilakukan berdasarkan well report (deskripsi cutting/core) dan log gammaray yang dapat mencerminkan lingkungan pengendapan suatu formasi. Sumur Alpha-1 dan Betha-1 terdiri dari empat formasidari tua ke muda yaitu Formasi Talang Akar, Formasi Gumai, Formasi Air Benakat dan Formasi Muara Enim yang dialasibasement berupa batuan metamorf dengan litologi berupa sekis.

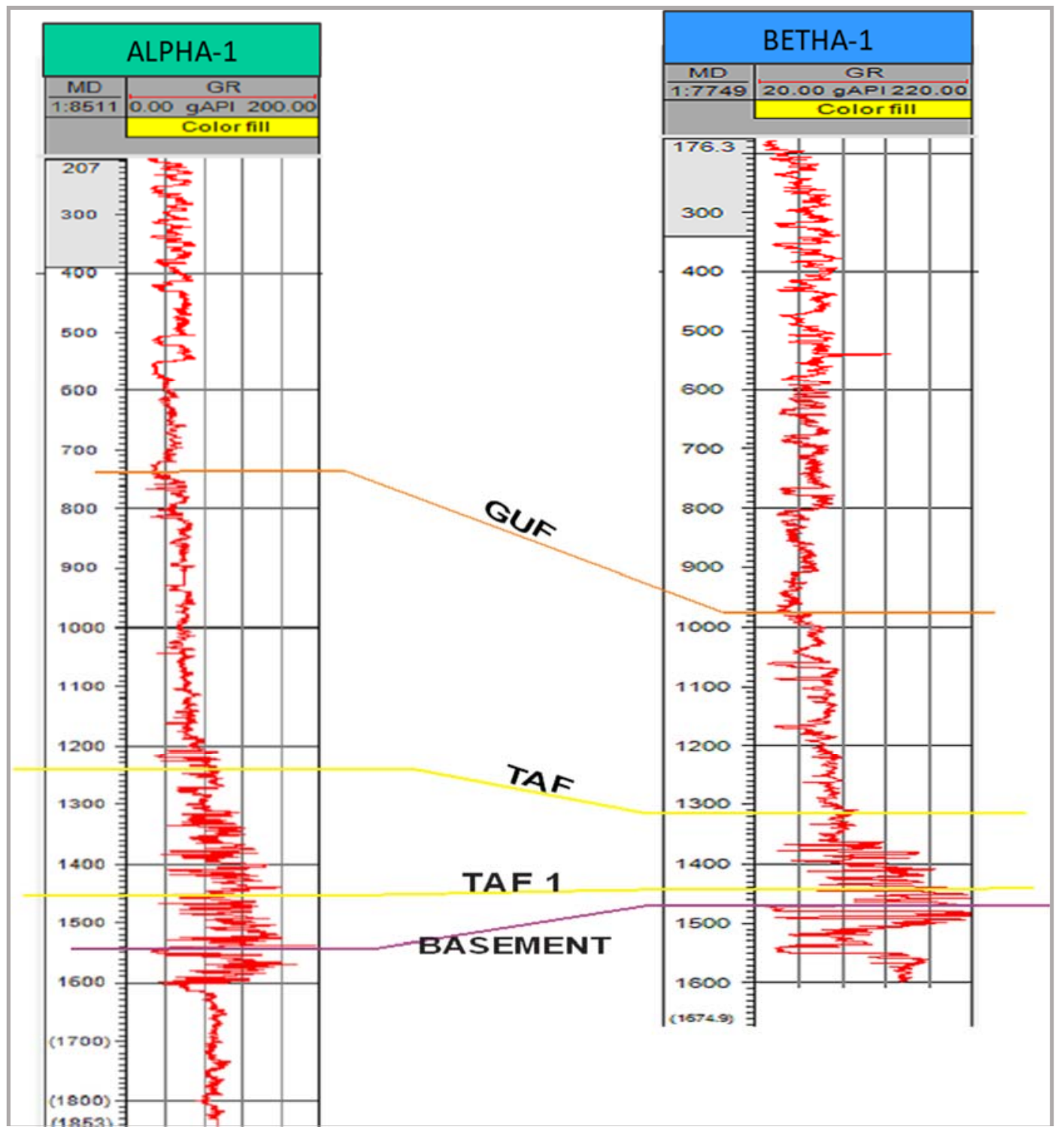

Gambar 6. Korelasi Zona Reservoir Sumur Alpha-1 dan Betha-1 
Korelasi zona reservoir antara sumur Alpha-1 dan Betha-1 dilakukan berdasarkan analisa peterofisika dan deskripsi cutting/core pada masing-masing sumur. Objek penelitian berada pada Formasi Talang Akar dengan kode marker TAF 1. Pada kedua sumur zona reservoir yang potensial tersebut diendapkan secara tidak selaras tepat di atas basement. Korelasi antara sumur dapat dilihat pada Gambar 6.

\subsection{Identifikasi Horison dan Sesar}

Reservoir yang telah diidentifikasi pada kedua sumur ini selanjutnya akan dijadikan marker untuk melakukan korelasi secara lateral karena pada dasarnya penyebaran properties reservoir secara lateral dilakukan dengan intepretasi horison pada data seismik.

Pada Gambar 7, pola diskontinuitas pada horison dapat merepresentasikan keberadaan patahan atau terdapatnya dislokasi kemenerusan refleksi. Pada daerah yang mengalami fase tektonik yang cukup hebat biasanya akan muncul pola-pola choatic sebagai respon rusaknya reflektor pada daerah yang tersesarkan.

Pergerakkan sesar dapat terbatas sepanjang sesar atau terdistribusi pada ruang yang berdekatan. Biasanya sesar memiliki garis lurus atau membelok sedikit pada arah tertentu.

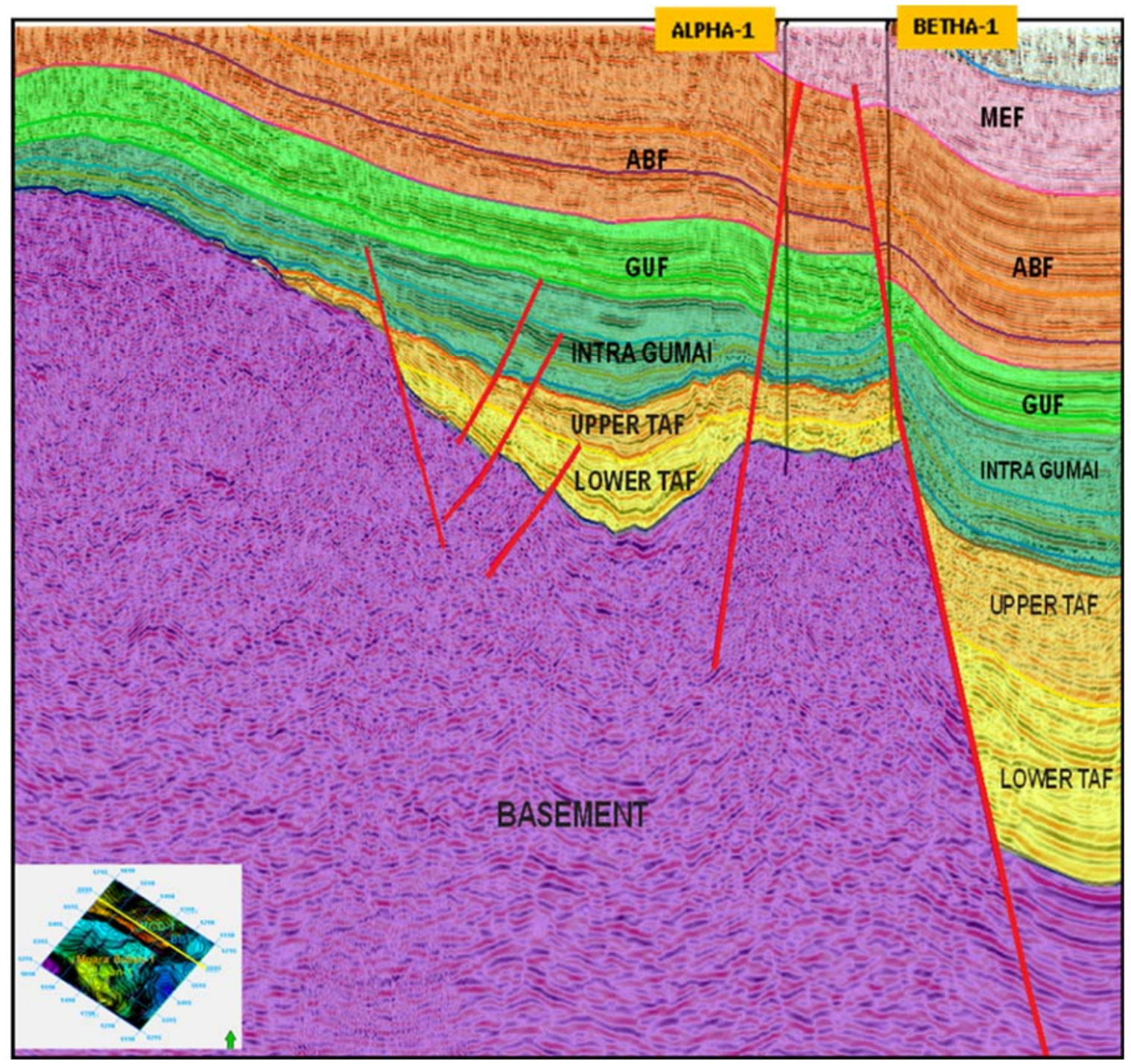

Gambar 7. Penampang Seismik 5602 
Berdasarkan intepretasi sesar dan horison yang dilakukan pada data seismik, terdapat sesar utama berupa reverse fault yang berarah Baratlaut - Tenggara dan beberapa normal fault yang berarah Baratdaya - Timurlaut yang juga diantaranya memisahkan dua sumur yang digunakan dalam penelitian dapat dilihat pada Gambar 8.. Objek penelitian pun dibatasi pada
Formasi Talang Akar, dikarenakan memiliki sifat yang baik sebagai reservoir (terdapat reservoir) dan mengalami dua fase tektonik (rifting dan compression), sehingga mengakibatkan reverse fault pada sesar normal yang dimungkinkan dapat memiliki gejala geologi menarik (dalam sudut pandang kesekatan sesar).

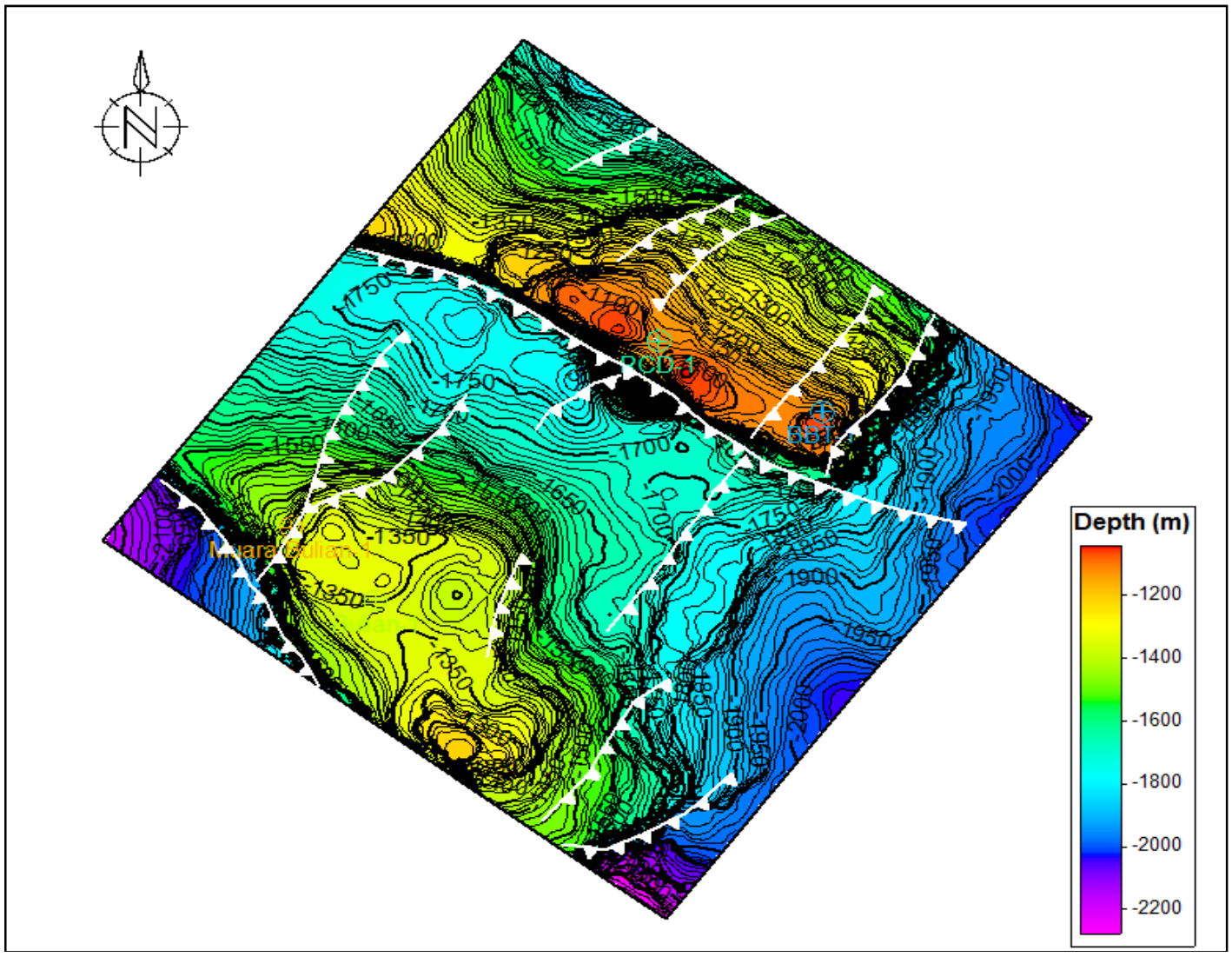

Gambar 8. Depth Structure Map

\subsection{Analisa Kesekatan Sesar}

Pada tahap pertama dalam analisa sifat kesesaran ini adalah melakukan analisa kandungan dedritus halus pada zona sesar yang biasa menjadikan sesar memiliki sifat sebagai jalur migrasi (leak) atau menjadi penutup (seal). Hal ini diperlukan untuk menentukkan pola kompartemenisasi lapisan yang menjadi tema dalam penelitian ini. Parameter dalam analisa ini adalah kandungan Vshale dan panjangnya dislokasi lapisan secara vertical (throw). Nilai throw ini akan berpengaruh pada kekedapan sesar, dimana semakin besar nilai pergeseran sesarnya (throw) akan semakin bagus sehingga kemungkinan untuk bertemunya batupasir (reservoir) dengan serpih (bukan reservoir) akan semakin besar. Dengan asumsi bahwa dislokasi yang besar akan menghasilkan butiran halus bersifat impermeable lebih banyak sehingga dapat mengakibatkan suatu sesar bersifat sebagai penyekat. Analisa kandungan Vshale pada lapisan yang mengalami pensesaran, perhitungan Vshale rata-rata dilakukan pada setiap sumur untuk masing-masing lapisan batuan reservoir maupun bukan reservoir yang dipisahkan oleh sesar, selanjutnya nilai Vshale tersebut diinterpolasi ke bidang sesar sehingga didapatkan atribut kandungan serpih sepanjang permukaan footwall dan 
hangingwall sesar (Yielding dkk, 1999). Atribut kandungan serpih bersama-sama throw fault digunakan untuk menghitung shale gauge ratio (SGR).

Nilai Vshale pada lapisan disekitar bidang sesar diperoleh/ditentukan berdasarkan nilai Vshale dari sumur-sumur yang menghimpit sesar (sumur Alpha-1 dan Betha-1), nilai Vshale adalah nilai Vshale lapisan yang terpisahkan sesar baik lapisan reservoir dan bukan reservoir. Bedasarkan hasil analisa petrofisika diperoleh kandungan volume serpih pada bidang sesar pada blok hanging wall dengan nilai $2.4-98 \%$, tetapi nilai volume serpih rerata pada daerah yang dianalisa (terpisahkan sesar) didapatkan sebesar 19\% (0.19) pada blok hanging wall dengan nilai delta $\mathrm{z}$ sebesar 10 meter. Dengan formula SGR seperti dituliskan pada persamaan di bawah ini.

$$
S G R=\frac{\Sigma(\text { Shale Bed Thickness })}{\text { Fault Throw }} .100 \%
$$

Berdasarkan hasil perhitungan didapat-kan nilai SGR (shale gouge ratio) pada sesar adalah 15.3\%. Menurut Yielding (2002) pada batuan silisiklastik di beberapa lapangan dunia menghasilkan batas SGR $<15-20 \%$ untuk kapasitas sesar berpotensi untuk bersifat bocor (leaking), maka dapat disimpulkan bahwa sifat kesesaran pada sesar yang diteliti ini sebagai jalan bermigrasi untuk fluida.

Perbedaan-perbedaan sifat petrofisika batuan (zona reservoir) yang tidak terlalu signifikan pada masing-masing sumur Alpha-1dan sumur Betha-1.

\subsection{Analisa Atribut Seismik}

Analisa atribut ini dilakukan untuk menunjang intepretasi berkaitan dengan pola kompatemenisasi lapisan ( pola kemenerusan lapisan dan keberadaan patahan). Atribut yang digunakan adalah ant tracking, instaneous phase dan envelope amplitude dikarenakan dapat menunjukkan adanya perubahan litologi yang tajam ataupun keberadaan sesar. Gambar 9 merupakan slicing penampang seismik yang telah dilakukaan atribut instaneous phase yang memiliki respon yang baik jika terdapat perubahan litologi secara tiba - tiba dan adanya pola ketidakmenerusan lapisan.

Pola - pola pemberhentian lapisan yang memiliki arah - arah kelurusan dapat diintepretasikan sebagai adanya sesar,sesar utama memiliki arah relatif BaratLaut - Tenggara memisahkan dua tinggian Bungin Batu dan Muara Bulian. Pola - pola kelurusan terdapat pada arah Baratdaya - Timurlaut sebagai sesar yang memisahkan tinggian Bungin Batu dan Rengan Condong.

Selain atribut instaneous phase dilakukan pula atribut ant tracking seperti ditunjukkan pada Gambar 10 untuk menunjang intepretasi sesar pada lokasi penelitian.

Perbedaan gradasi warna dapat diakibatkan oleh sifat fisika yang berbeda pada sebuah lapisan batuan, yang menarik pada slicing ini adalah pola - pola patahan yang ada pada atribut ini memiliki pola serupa dengan hasil slicing pada atribut instaneous phase. Peta hasil slicing pada horizon menunjukkan hal yang sama yaitu antara sumur Dahlia dan Teratai dipisahkan oleh sebuah sesar yang berarah relatif Timurlaut - Baratdaya. Untuk menunjang intepretasi sebelumnya yang menunjukkan pola pemberhentian lapisan, maka dilakukan atribut RMSamplitude seperti ditunjukkan pada Gambar 11.

Atribut RMS amplitude digunakan untuk mengetahui pola kemenerusan lapisan yang putus dikarenakan adanya sesar. Atribut ini digunakan untuk menunjang intepretasi keberadaan sesar dan analisa kompartemen dari reservoir. Sesar akan mengakibatkan dislokasi kemenerusan lapisan dengan besar throw tertentu. Kombinasi antara atribut RMS amplitude, ant tracking dan instaneous phase diharapkan mampu mendeteksi adanya patahan dan kemenerusan lapisan yang tersesarkan. 


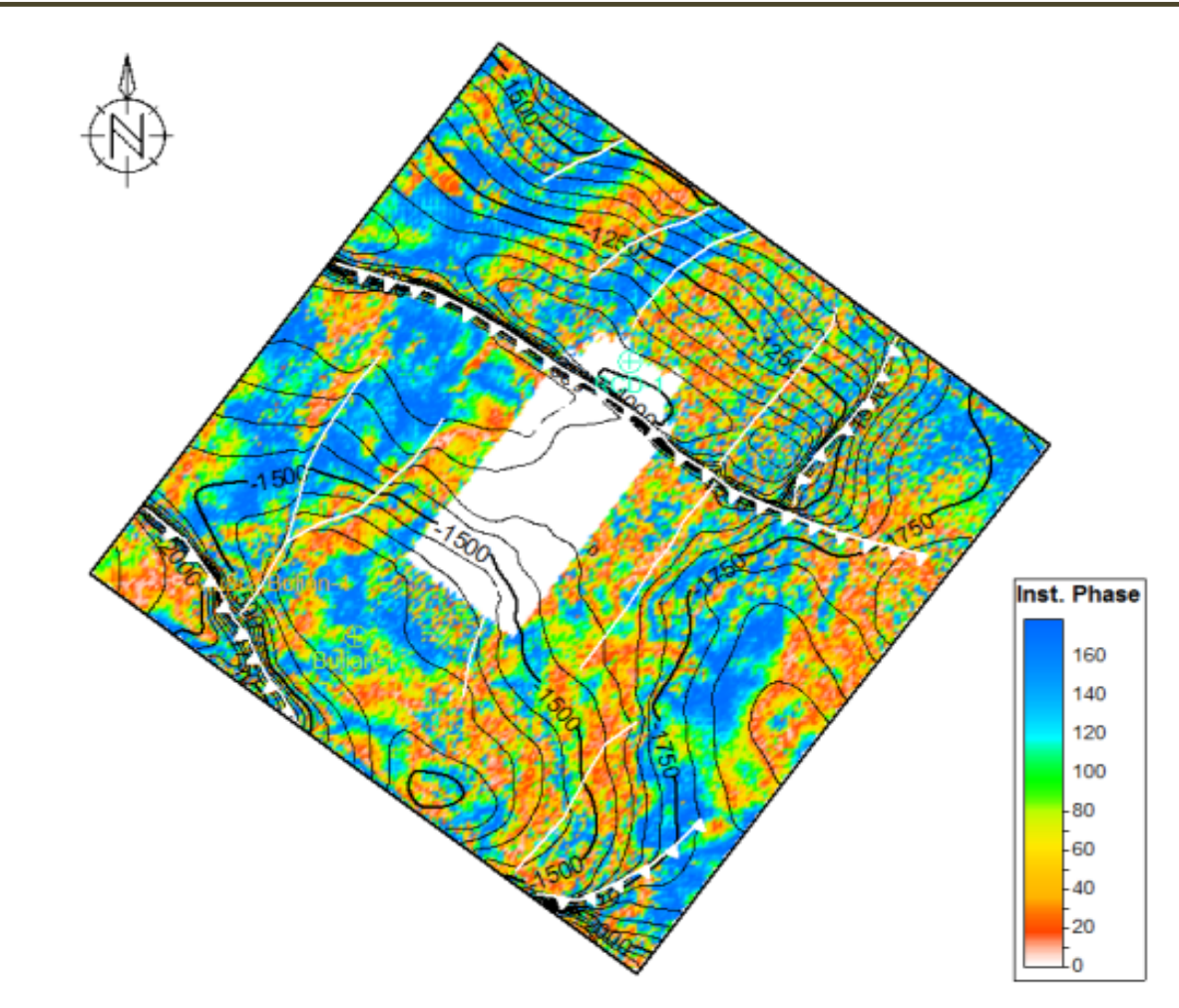

Gambar 9.Slicing Instaneous Phase HarizonTAF 1

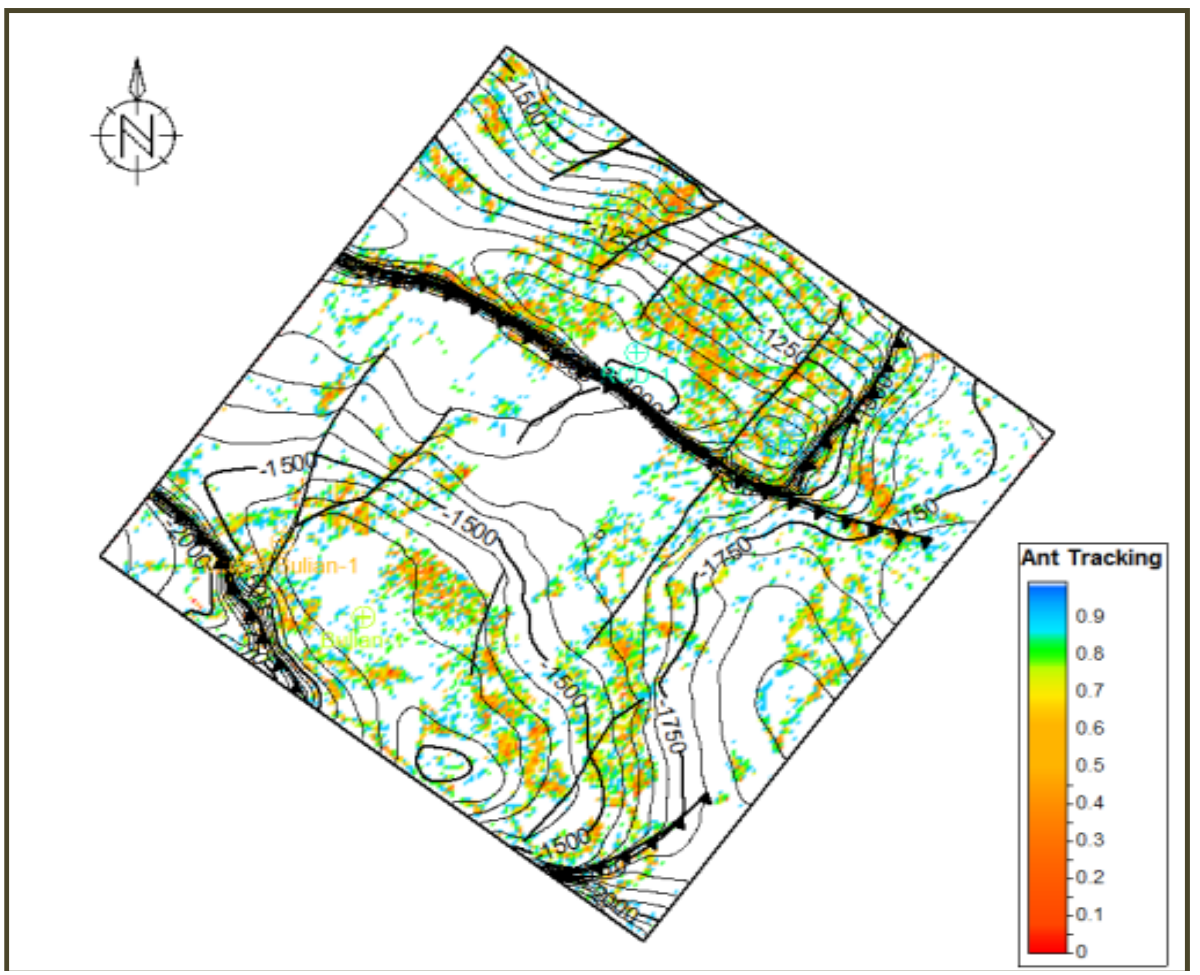

Gambar 10. Slicing Ant Tracking HarizonTAF 1 


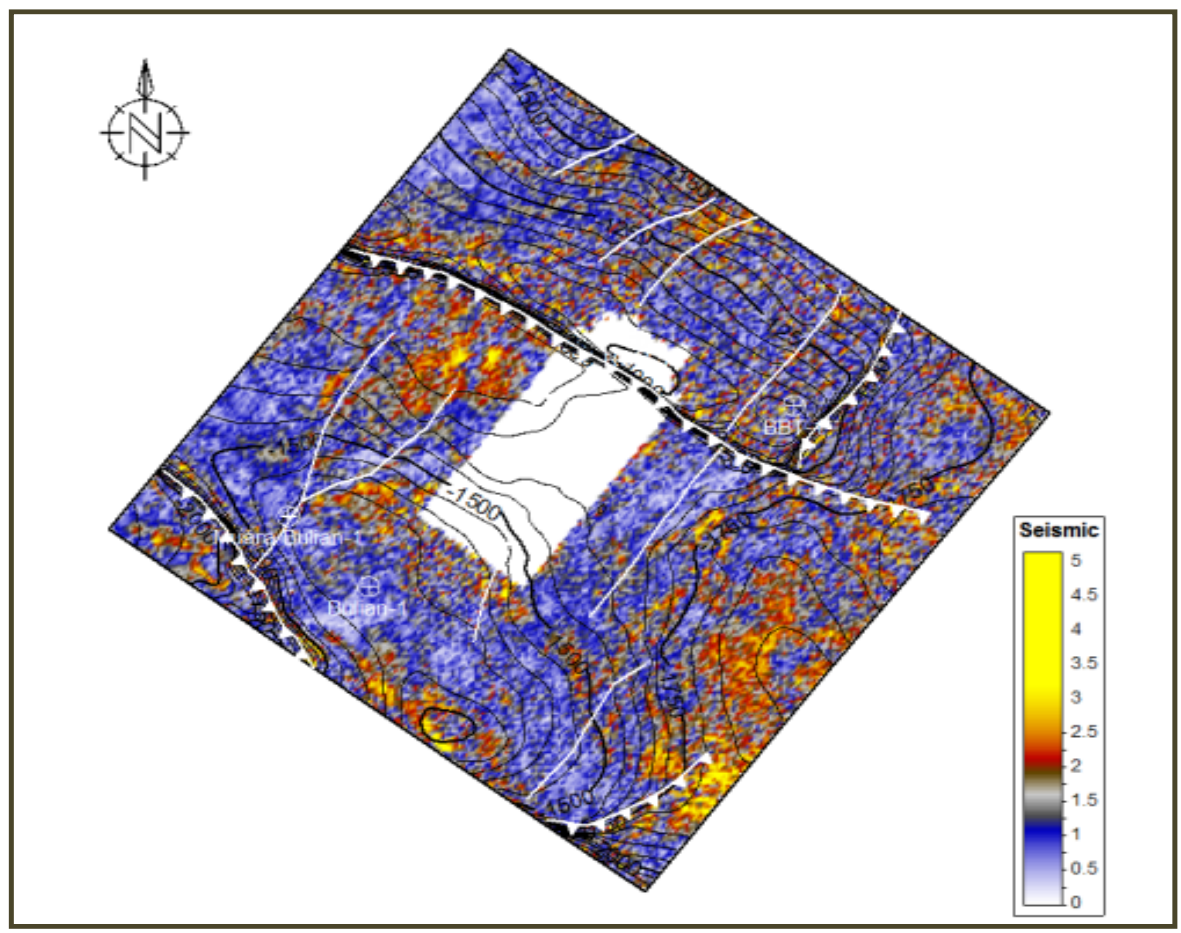

Gambar 11. Slicing RMS Amplitude HarizonTAF 1

\section{Kesimpulan}

Analisis yang dilakukan pada hasil data seismik dan sumur pada Lapangan X, maka dapat disimpulkan sebagai berikut :

1. Berdasarkan intepretasi data sumur yang dilakukan pada sumur Alpha-1 dan Betha-1 terdapat beberapa lapisan prospek dengan litologi batupasir. Sementara obyek dalam penelitian ini merupakan reservoar batupasir dari Formasi Talang Akar pada kedalaman 1436-1456 m pada sumur pertama dan 1448 1456 m pada sumur kedua.

2. Berdasarkan analisis data log lapisan reservoar pada sumur Alpha-1 yang berada pada kedalaman 1436-1456 m memiliki porositas efektif rata-rata 0,1281 , saturasi air rata-rata 0,34 dengan permeabilitas rata-rata pada zona ini adalah $20,62 \mathrm{mD}$ dengan nilai $R_{t}$ rata-rata $1794 \mathrm{ohm} \mathrm{m}$ dan $R_{w} 0,4 \mathrm{ohm} \mathrm{m}$. Sedangkan pada sumur BETHA-1 yang berada pada kedalaman 1448-1456 m memiliki porositas efektif rata-rata pada zona ini 0,129 saturasi air rata-rata 0,586 , permeabilitas $19,6 \mathrm{mD}$ dengan nilai $R_{t}$ rata-rata $32.2 \mathrm{ohm} \mathrm{m}$ dan nilai $R_{w} 0,9$ ohm m.

3. Berdasarkan analisisShale Gauge Ratio yang dilakukan pada sesar turun geser yang menjadi objek penelitian ini didapatkan nilai SGR $15 \%$ yang dapat diintepretasikan bahwa sesar ini bersifat leak atau menjadi media bermigrasi fluida. Migrasi fluida berasal dari lapisan source rock yang berada di bawahnya (intra formasi).

4. Berdasarkan slicing yang dilakukan terhadap attribute seismik didapatkan indikasi bahwa lapisan prospek pada kedua sumur ini memiliki komunikasi atau reservoar yang sama (satu kompartemen) yang tersesarkan.

\section{Daftar Pustaka}

Anonim, 1998, POD Struktur Bungin Batu dan Rengan Condong, Pertamina.

Barnes, A.E.. 1999. Seismic attributes past, present, and future: 69th Annual Internat. Mtg., Soc. Expl. Geophys., Expanded Abstracts, 892-895.

Chien, Q., dan Sidney, S., 1997, Seismic Attribute Technology for Resevoir Forecasting and Monitoring, Western Atlas International Inc., Houston, Texas.

Dee, S, 2005 :Faults Seal Analysis Training Course, Badley TrapTester Version 5.3, Jakarta.

Fisher,Q.J., Jones, G. dan Knipe,R.J. 1998. Faulting, Fault Sealing and Fluid Flow in Hydrocarbon Reservoirs. The Geological Society, London, UK. 
Ginger, D. dan Fielding, K., 2005, The Petroleum System And Future Potential Of The South Sumatra Basin. Indon. Petroleum Assoc. 30 th Ann. Conv. Proc., p. 67-89.

Lindsay, N.G., Murphy, E.C., Walsh, dan J.J., Watterson, J., 1993. Outcrop studies of shale smears on fault surface. International Association of Sedimentology.

Smith, D. A., 1980, Sealing and Nonsealing Faults in Lousiana Gulf Coast Salt Basin, The American Association of Petroleum Geologist Bulletin, v. 64, p. 145-172.

Watts, N., 1987. Theoritical aspects of cap rock and faults seals for single and two- phase hydrocarbon columns. Mar. Pet. Geol.
White, R.E., 1991, Properties of instantaneous seismic attributes: The Leading Edge, 10, no. 7, 26-32.

Yielding, G., B. Freeman., dan D.T. Needham, 1997, Quantitative Fault Seal Prediction, The American Association of Petroleum Geologist Bulletin, v. 81, p. 897-917.

Yielding, G., 2002, Shale Gouge Rati-Calibration By Geohystory, NPF Special Publication 11, p. 1-15.

Yielding, G., Overland, J.A., dan Byberg, G., 1999, Characterization of Fault Zones for Reservoir Modeling : An Example from The Gullfaks Field, Northern Sea. The American Association of Petroleum Geologist Bulletin, v. 83 , p. 92 